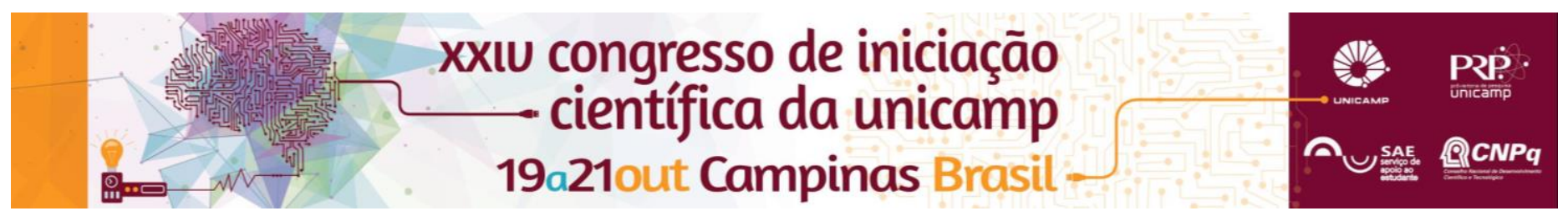

\title{
Solubilidade e Coeficiente de Partição Octanol/Água (Kow) do Corante Disperso RED 13
}

\section{Mariana Rizzo Mattiuzzo*, Enelton Fagnani.}

\section{Resumo}

A capacidade de uma substância se dissolver em água é denominada solubilidade. O Coeficiente de Partição octanol/água se refere à distribuição de determinada substância entre dois meios líquidos de polaridade bastante distinta. O trabalho objetiva a determinação destes dois importantes parâmetros para um azo corante com potencial tóxico, o vermelho disperso 13 (disperse red 13).

Palavras-chave: ecotoxicidade, parâmetros físico-químicos, otimização de metodologias analíticas.

\section{Introdução}

Os corantes vêm sendo cada vez mais estudados devido às suas características tóxicas e por serem potencialmente carcinogênicos ${ }^{1}$. O corante RED 13 possui a seguinte estrutura molecular (Fig 1):<smiles>CCN(CCO)c1ccc(N=Nc2ccc([N+](=O)[O-])cc2Cl)cc1</smiles>

Figura 1. Fórmula estrutural do corante RED 13.

Para o estudo do Kow foi utilizado método da agitação lenta, ideal para substâncias apolares². Foi utilizado um extrator contendo um líquido polar e outro apolar (Fig 2)

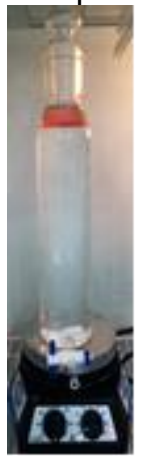

Figura 2 - Extrator

O valor de Kow, representado por "P" pode ser calculado utilizando a seguinte equação:

$$
\mathrm{P}=\frac{[\mathrm{Y}] \text { Fase rica em octano] }}{[\mathrm{X}] \text { Fase rica em água }}
$$

\section{Resultados e Discussão}

As análises foram realizadas separadamente em relação ao $\mathrm{pH}$, seguindo a ordem do fluxograma a seguir.
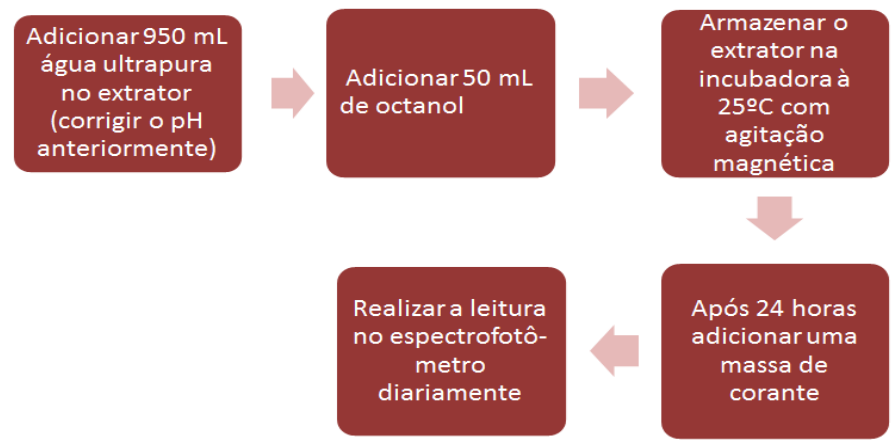

Os espectros referentes ao DR 13 ao longo dos experimentos podem ser vistos na Figura 3.
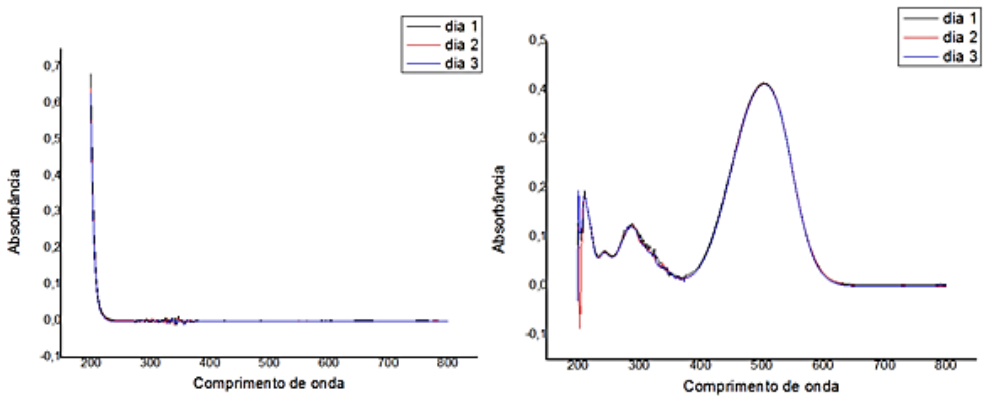

Figura 3 - Leitura em água e octanol, respectivamente.

Após três dias observamos que o espectro do octanol se estabilizou, porém é necessário repetir o experimento pois houveram alguns desvios que podem ter sido causados por impurezas no líquido ou na cubeta. Com relação à solubilidade, não foi possível quantificá-la através do método utilizado.

\section{Conclusões}

Foi possível observar que, como previsto, o corante disperso RED 13 é esparsamente solúvel em água e possui coeficiente de partição octanol/água elevado, portanto deve se bioacumular em sedimentos e gordura.

\section{Agradecimentos}

Agradecemos aos amigos e colegas que estiveram presentes no decorrer do projeto e aos técnicos do laboratório que sempre nos auxiliaram quando necessário.

\footnotetext{
${ }^{1}$ BAUGHMAN, G.L., PERENICH, T.A. Fate of dyes in aquatic systems. Environm. Toxicol. Chem., v. 7, p. 183-199, 1988.

2 OECD (2006) OECD Guidelines for the Testing of Chemicals: 123 Partition Coefficient (1-Octanol/Water): Slow- Stirring Method. Paris.
} 